\title{
REGULATION OF GROWTH OF LNCaP HUMAN PROSTATE TUMOR CELLS BY GROWTH FACTORS AND STEROID HORMONES
}

\author{
A. L. G. Schuurmans, ${ }^{*}$ J. Bolt, J. Veldscholte and E. Mulder ${ }^{\dagger}$ \\ Department of Endocrinology and Reproduction, Erasmus University Rotterdam, Rotterdam, \\ The Netherlands
}

\begin{abstract}
Summary - The mitogenic activity of several growth factors on androgen responsive LNCaP human prostate tumor cells was studied. A two-fold stimulation of cell proliferation was observed after a culture period of 6 days in $1 \mathrm{ng} \mathrm{EGF/ml,} 10 \mathrm{ng} \mathrm{TGF}-\alpha / \mathrm{ml}$ or $20 \mathrm{ng}$ basic FGF $/ \mathrm{ml}$. TGF $-\beta(0.02 \mathrm{ng} / \mathrm{ml})$, which did not affect cell proliferation when added alone to the culture medium, inhibited the EGF- and TGF- $\alpha$-induced growth. The synthetic androgen R1881 $(0.1 \mathrm{nM})$ stimulated cell proliferation three-fold and increased the number of EGF receptors from 11500 to 28500 sites/cell. One of the mechanisms involved in androgen action on these cells is therefore an increased EGF receptor expression and increased sensitivity to EGF. TGF- $\beta$ did not directly affect androgen-responsive growth but inhibited the synergistic effect of EGF. A considerable expression of TGF $\alpha$ (precursors) could be demonstrated on the cells by immunohistochemical staining. However the staining intensity was not affected by androgens. These results make it less likely that androgen-responsive growth is mediated by regulation of secretion of an EGF- or TGF $\alpha$-like activity, which in turn acts in an autocrine manner to stimulate growth.

Estrogens, progestagens and antiandrogens do not inhibit androgen responsive growth of LNCaP cells but have striking growth stimulatory effects, increase EGF receptor level and increase acid phosphatase secretion. LNCaP cells contain a modified androgen receptor system with respect to both steroid specificity and antiandrogen sensitivity. It has recently been shown that the stimulatory effects are due to a mutated amino acid in the steroid binding domain of the androgen receptor.
\end{abstract}

\section{INTRODUCTION}

The prostate gland is dependent on androgens for the maintenance of its growth and functional integrity [1]. Androgens exert their effects on target tissue through binding to the androgen receptor, followed by association of the androgen receptor complex with specific binding sites on DNA $[2,3]$. This androgen receptor complex can either induce [4] or repress [5] transcription of specific genes.

Steroid hormones and growth factors are involved in the complex regulation of cell proliferation of hormone sensitive tumors. For example, in human breast cancer cells, estrogens exert their action through coordinated control

Proceedings of the VIIIth International Congress on Hormonal Steroids, The Hague, The Netherlands, 16-21 September 1990.

*Present address: Department of Endocrinology, Wilhelmina Kinderziekenhuis, Utrecht, The Netherlands.

$\dagger$ To whom correspondence should be addressed: Dr E. Mulder, Biochemistry II, Room EE 526, Erasmus University Rotterdam, P.O. Box 1738, 3000 DR Rotterdam, The Netherlands. of production and secretion of a collection of growth factors [6]. These growth factors act in an autocrine or paracrine way by binding to their cell surface receptors. In addition, steroid hormones may control cell proliferation by modulating the affinity or level of expression of growth factor receptors $[7,8]$.

The information on the effects of hormones and growth factors on human prostate cell lines is scarce, because of the very limited number of androgen-responsive cell systems. Among the six permanently growing human prostate cell lines described up to now [9] only the LNCaP (lymph node carcinoma of the prostate) cell line developed by Horoszewicz [10] shows androgendependent growth [11]. LNCaP cells contain considerable amounts of androgen receptors while estrogen and progestagen receptors are not detectable [12]. Androgen treatment of these cells enhances the synthesis and secretion of prostate specific acid phosphatase (PAP) [13].

In this paper we review studies performed in our laboratory with respect to different aspects of the growth stimulation of $\mathrm{LNCaP}$ cells. 
Firstly, we describe in vitro studies, which suggest that the androgens not only directly affect cell growth, but also act indirectly by making the cells more sensitive for growth factor mediated stimuli $[14,15]$. Thereafter, effects of growth factors are described and mechanisms of growth stimulation discussed in relation to the enhanced expression of $\mathrm{TGF} \alpha$ precursors on the cells. In the last part we describe the aberrant specificity of the androgen receptor system of the $\mathrm{LNCaP}$ cells, leading to growth stimulatory effects of progestagens, estrogens and antiandrogens [12, 16-18].

\section{EFFECT OF ANDROGENS ON EGF RECEPTOR LEVELS}

EGF binding data revealed an increase of EGF binding to LNCaP cells treated with androgen vs control cells. When assayed at $0^{\circ} \mathrm{C}$, a temperature at which internalization of the complex of EGF and its receptor plays no significant role, EGF binding to androgentreated cells was increased more than two-fold. Only one type, high affinity binding sites were found. A rise in EGF receptor levels was first observed between 6 and $12 \mathrm{~h}$ after addition of androgens (Table 1), which is in line with the comparatively late effects of androgens on induction of new protein synthesis.

Actinomycin-D and cycloheximide inhibited the hormonally-induced increase in EGF receptor numbers. This indicates that the EGF receptor induction process is, at least in part, regulated at transcriptional level. Increase of transcription of specific genes by steroids has been described for several systems. Up-regulation of EGF receptor levels was for example seen in several cells upon treatment with glucocorticoids and progesterone $[7,8]$. In contrast to these and our findings, androgen downregulation has been demonstrated in normal rat prostate [19] and in non-neoplastic canine pro-

Table I. Time-course of androgen effect on EGF receptor activity of LNCaP cells

\begin{tabular}{|c|c|c|c|}
\hline \multirow[b]{2}{*}{ Period } & \multicolumn{2}{|c|}{ Sites/cell } & \multirow{2}{*}{$\begin{array}{c}\text { Stimulation } \\
\text { factor } \\
\text { (B/A) }\end{array}$} \\
\hline & Control (A) & R1881 (B) & \\
\hline $3 \mathrm{~h}$ & 11,250 & 12,010 & 1.07 \\
\hline $6 \mathrm{~h}$ & 11,250 & 13,030 & 1.16 \\
\hline $12 \mathrm{~h}$ & 15,680 & 19,930 & 1.27 \\
\hline $24 \mathrm{~h}$ & 11,800 & 20,730 & 1.76 \\
\hline 3 days & 10,540 & 21,890 & 2.08 \\
\hline 6 days & 12,560 & 28,940 & 2.30 \\
\hline
\end{tabular}

Cells were cultured in medium with $5 \%$ charcoal-stripped serum in the presence or absence of $0.1 \mathrm{nM}$ of the synthetic androgen $\mathrm{R} 1881$ for the period indicated; EGF receptors were measured thereafter at $0^{\circ} \mathrm{C}$ static cell lines [20]. Thus in the normal prostate, androgens may prevent growth by down-regulation of EGF receptors while in transformed LNCaP cells androgens up-regulate EGF receptors which correlates with increased growth. In human prostatic tumors EGF receptor levels are higher in poorly differentiated tumors with decreased androgen receptor level [21]. This might indicate a constitutively increased expression of EGF receptors after dedifferentiation and loss of steroid receptors. Comparable observations have been made for estrogen receptor positive and negative cell lines [22].

\section{EFFECT OF GROWTH FACTORS}

The effect of different growth factors on LNCaP cell cultures is shown in Table 2. Cell proliferation is stimulated by epidermal growth factor (EGF) and transforming growth factor alpha (TGF $\alpha)$. In addition basic fibroblast growth factor and, to a lesser extent, acidic fibroblast growth factor can stimulate the proliferation of $\mathrm{LNCaP}$ cells. No stimulation was found with insulin, insulin-like growth factor one (IGF-I) or platelet derived growth factor (PDGF). Table 2 shows that EGF acted synergistically with R1881 on $\mathrm{LNCaP}$ to induce cell growth (six-fold increase). This effect was only observed when the culture medium with hormone was changed daily. TGF $\beta$ counteracts the stimulatory effect of EGF both in the presence and absence of the synthetic androgen R1881. TGF $\beta$ has only a limited (not significant) effect

Table 2. Effect of different growth factors on LNCaP cells

\begin{tabular}{|c|c|c|}
\hline $\begin{array}{l}\text { Growth factors } \\
\text { and steroids }\end{array}$ & $\begin{array}{c}\text { Growth factor } \\
(\mathrm{ng} / \mathrm{ml})\end{array}$ & $\begin{array}{c}\text { Stimulation } \\
\text { factor }\end{array}$ \\
\hline EGF & 0.1 & 1.2 \\
\hline EGF & l & 2.2 \\
\hline EGF & 10 & 2.1 \\
\hline $\mathrm{R} 1881^{\mathrm{a}}$ & & 3.7 \\
\hline $\mathrm{R} 1881^{\mathrm{a}}+\mathrm{EGF}$ & 1 & 6.0 \\
\hline $\mathrm{R} 1881^{\mathrm{a}}+\mathrm{EGF}+\mathrm{TGF} \beta^{\mathrm{b}}$ & 1 & 3.8 \\
\hline Basic FGF & 5 & 1.3 \\
\hline Acidic FGF & 20 & 1.9 \\
\hline TGF $\alpha$ & 1 & 1.3 \\
\hline TGF $\alpha$ & 5 & 1.9 \\
\hline $\mathrm{TGF} \alpha$ & 10 & 2.4 \\
\hline $\mathrm{TGF} \alpha+\mathrm{TGF} \beta^{\mathrm{b}}$ & 10 & 1.4 \\
\hline
\end{tabular}

Effects of different growth factors at various concentrations on LNCaP cells. DNA content per culture was measured after 6 days treatment with indicated growth factors and steroid (synthetic androgen R1881) and was expressed relative to DNA content of control cultures without additions. Mean values of triplicate cultures are shown. EGF: epidermal growth factor; FGF: fibroblast growth factor; TGF $\alpha$ : transforming growth factor alpha; TGF $\beta$ : transforming growth factor beta. ${ }^{\text {a The }}$ $\mathrm{R} 1881$ concentration was $0.1 \mathrm{nM}$. ${ }^{\mathrm{b}}$ Addition of $0.05 \mathrm{ng} / \mathrm{ml}$ TGF $\beta$. 
on R1881-stimulated cell growth and had no effect when added to the culture medium alone.

The absence of a direct effect of TGF $\beta$ on LNCaP cells was also found by Wilding et al. [23]; on the contrary human independent PC-3 and influence cells were inhibited by TGF $\beta$. These authors did not find TGF $\beta$ receptors in LNCaP cells. Our results may suggest that after EGF stimulation TGF $\beta$ is able to bind to $\mathrm{LNCaP}$ cells to exert its inhibitory effect.

The results obtained in the studies with combinations of the growth factors EGF and TGF $\beta$ make it less likely that androgen-responsive growth is mediated by regulation of secretion of an EGF-like activity which in turn acts in an autocrine manner to stimulate growth. If the latter mechanism played a role one would expect that TGF $\beta$ inhibits the growth response to this autocrine EGF-like activity in a comparable way as observed for exogenously added EGF.

\section{LNCaP CELLS PRODUCE TGF $\alpha$ PROTEIN}

In contrast to EGF, TGF $\alpha$ synthesis is most prevalent and abundant in tumor cells and cells transformed by retroviruses, oncogenes or chemicals. The precursor of TGF $\alpha$ (pro-TGF $\alpha$ ) occurs as a membrane protein [24]. Release of the mature TGF $\alpha$ from the outer domain of pro-TGF $\alpha$ occurs through proteolytic action of elastase-like enzymes. A variety of transformed cells, including human tumor cells also secrete larger forms of TGF $\alpha$ in varying proportions [24], suggesting that the elastase-like cleavage is incomplete.

Furthermore, pro-TGF $\alpha$ expressed on the cell surface, has been shown to bind to EGF receptors on adjacent cells, leading to signal transduction $[25,26]$. This observation has led to the hypothesis of juxtacrine growth stimulation.

We have used an anti-TGF $\alpha$ antibody in experiments to detect TGF $\alpha$ by an immunohistochemical approach. This antibody [27] was produced from hybridomas from mice immunized with a 17 -residue synthetic peptide corresponding to the carboxyl terminal sequence of rat $\mathrm{TGF} \alpha$. The antibody (MF9) recognizes human TGF $\alpha$ but not EGF [27]. For immunohistochemical staining the LNCaP cells were grown on culture slides and after fixation incubated with the monoclonal antibody. Intense staining could be observed after visualization of bound antibody (peroxidase-conjugated second antibody procedure). Staining was dependent on the presence of MF9 antibody. However the staining was not affected by the level of androgens present in the medium used for culture of the cells, in line with previous observations [28] that TGF $\alpha$ mRNA is not regulated by androgens in LNCaP cells. These results do not support the presence of an autostimulatory growth loop in hormone-responsive human prostate cancer cells as shown in another study [29]. On the contrary our results support the conclusions reached by Connolly and Rose [30], who recently found large amounts of EGF-related polypeptides in LNCaP-cells by radioreceptor assay, but did not observe a significant effect of dihydrotestosterone on EGF or TGF $\alpha$ synthesis and secretion. In addition they observed a striking difference between the androgen-independent DU 145 and androgendependent LNCaP cells with respect to EGF secretion, the concentration of EGF in media conditioned by DU 145 cells was more than ten times higher than in media from $\mathrm{LNCaP}$ cells. In our studies we observed that $\mathrm{LNCaP}$ cells cultured in the absence of serum showed an increased proliferation rate when cells were cultured at high density. It is therefore tempting to speculate that at high cell density androgenindependent growth is favored by juxtacrine effects of TGF $\alpha$ precursors anchored in the cell membrane that interact by direct cell-cell contact with EGF receptors on other cells. Recently Knabbe et al. [31] were able to distinguish two different mechanisms of growth regulation for prostate tumor cells in culture: a hormonedependent pathway largely independent of extracellular growth factors and a hormoneindependent pathway, mediated by excreted TGF $\alpha$ that could be blocked by the polyanions dextran-sulphate and suramin. In our hands suramin gives complete, but reversible inhibition of both hormone and growth factor mediated cell proliferation [32]. On the other hand the concept of the presence of two different regulatory pathways in human prostate tumor cells is attractive. In this scheme the androgen regulated pathway is only partly dependent on growth factors, in line with our observations that LNCaP cells are hormonally stimulated in growth factor depleted and serum free medium [14], although a synergistic effect on growth rate is obtained with exogenously added EGF, due to the increased expression of EGF receptors under the influence of androgens. For the androgen-independent growth an autocrine mechanism may exist, either mediated by excreted growth factors (as TGF $\alpha$ ) [29-31] 
or by a juxtacrine effect of growth factor precursors as described above. This second pathway may become more prevalent in the course of the development of hormone independence of prostate tumors in the in vivo situation.

\section{STEROID SPECIFICITY OF THE ANDROGEN RECEPTOR AND GROWTH OF LNCAP CELLS}

The $\mathrm{LNCaP}$ cell line has been described as a model for prostate cancer [10]. LNCaP cells contain considerable amounts of androgen receptors $(920 \mathrm{fmol} / \mathrm{mg}$ cytosol protein), while progestagen, estrogen and glucocorticoid receptors were absent [12]. Interestingly, progesterone as well as estradiol can stimulate the growth of LNCaP cells (Table 3). These results indicate a sensitivity for non-androgenic steroids. Progesterone or estradiol also increase the number of EGF receptors expressed at the cell surface of LNCaP cells. The relative binding affinity of the androgen receptor for the various steroids parallels the effects on cell growth; steroids with a high affinity for the androgen receptor stimulate cell growth at lower concentrations than steroids with lower affinity for the androgen receptor (Table 3 ). In contrast to expectation antiandrogens (cyproterone acetate and anandron) do not antagonize the androgen-responsive growth of LNCaP cells, but have striking stimulatory effects on the growth of the cells $[16,33]$. The two antiandrogens also increase the number of EGF receptors expressed at the cell surface and increase the secretion of prostate specific acid phosphatase in the culture medium by LNCaP cells (Table 3). These results lead to the conclusion that LNCaP cells contain a modified androgen receptor system both with respect to steroid specificity and antiandrogen sensitivity.

Table 3. Relative binding affinity and effect of different steroids and antiandrogens on LNCaP cells

\begin{tabular}{lcccc}
\hline Condition & RBA & \% Growth & $\%$ EGF R & $\%$ PAP \\
\hline Control (no steroid) & - & 100 & 100 & 100 \\
R1881 0.1 nM & 1 & 380 & 250 & 350 \\
Progesterone 1 nM & 0.3 & 350 & 180 & NE \\
Estradiol 10 nM & 0.04 & 350 & 220 & NE \\
CPA 100 nM & 0.12 & 350 & 200 & 400 \\
Anandron 100 nM & 0.01 & 300 & 220 & 200 \\
\hline
\end{tabular}

RBA: relative binding affinity, measured in competition assays. The affinity for R188I was set at 1. EGF R: EGF receptor; PAP: prostate acid phosphatase excreted. The different parameters were measured after 6 days culture and compared to controls in the absence of hormones (set at $100 \%$ ). NE: not estimated. CPA, cyproterone acetate, obtained from Schering, Berlin. Anandron, RU 23908, obtained from Roussel Uclaf, Paris.
Since the LNCaP cell line is the only in vitro growing androgen-responsive prostate tumor system of human origin it is not possible to investigate if loss of proper response to antiandrogens by metastatic prostate tumor cells is a general phenomenon for this type of cells in culture. However, it was recently shown ([18] and S. E. Harris et al., communicated at the Endocr. Soc. Mtg U.S.A., 1990) that the androgen receptor in $\mathrm{LNCaP}$ cells contains a mutation at amino acid 868 (thr-ala) in the C-terminal part of the steroid binding domain. The mutation is present in an essential region of the steroid binding domain of the receptor. At the similar position in the glucocorticoid receptor a cysteine (cys 754) can be covalently linked to the glucocorticoid triamcinolone acetonide by photo-affinity labeling [34]. One of the mechanisms by which antihormones might antagonize steroid hormones at the molecular level is at the level of transcription. Upon binding of the antihormone to the receptor, this complex probably either fails to bind to a hormone-responsive element on DNA or fails to induce the transcription activation function [35]. Recently we confirmed in transfection experiments with either the normal or the mutated androgen receptor, transfected together with an androgen-sensitive reporter gene into Hela cells, that the changed steroid sensitivity and stimulation by antiandrogens was solely due to the mutation in the androgen receptor (to be published elsewhere). In vivo in advanced metastatic prostate cancer tumors may pass through a stage in which they are stimulated by antiandrogens or estrogens. It remains to be established if an unfavorable response to hormonal therapy of prostate cancer in a certain group of prostate tumors in patients is also related to changes in the androgen receptor structure, or if the in vitro growing, androgensensitive prostate tumor cell line $\mathrm{LNCaP}$ is an exception in this respect.

Acknowledgements-The author wishes to thank Dr J Dorrington and Dr K. Teerds for advice and help with the immunohistochemical experiments. The work reported in this manuscript was supported by the Dutch Cancer Society (KWF) through Grants IKR 85-8 and 90-13.

\section{REFERENCES}

1. Sandberg A. A.: Endocrine control and physiology of the prostate. Prostate 1 (1980) 169-184.

2. Rushmere N. K., Parker M. G. and Davies P.: Androgen receptor binding regions of an androgen-responsive gene. Molec. Cell. Endocr. 51 (1987) 259-265. 
3. Claessens F., Celis L., Peeters B., Heyns W. Verhoeven G. and Rombauts W.: Functional characterization of an androgen response element in the 1st intron of the $\mathrm{C} 3(1)$ gene of prostatic binding protein. Biochem. Biophys. Res. Commun. 164 (1989) 833-840.

4. Zhang Y. L. and Parker M. G.: Regulation of prostatic steroid binding protein RNAs by testosterone. Molec. Cell. Endocr. 43 (1985) 151-154.

5. Montpertit M. L., Lawless K. R. and Tenniswood M.: Androgen repressed messages in the rat ventral prostate. Prostate 8 (1986) 25-36.

6. Dickson R. B. and Lippman M. E.: Estrogenic regulation of growth and polypeptide growth factor secretion in human breast carcinoma. Endocrine Rev. 8 (1987) 29-43.

7. Fanger B. O., Viceps-Madore D. and Cidlowski J. A.: Regulation of high- and low-affinity epidermal growth factor receptors by glucocorticoids. Archs Biochem. Biophys. 235 (1984) 141-149.

8. Murphy L. J., Sutherland R. L., Stead B., Murphy L. C. and Lazarus L.: Progestin regulation of epidermal growth factor receptor in human mammary carcinoma cells. Cancer Res. 46 (1986) 728-734.

9. Isaacs J. T.: Development and characteristics of the available animal model systems for the study of prostate cancer. In Current Concepts and Approaches to the Study of Prostate Cancer (Edited by D. S. Coffey). Liss, New York, Vol. 239 (1987) pp. 513-576.

10. Horoszewicz J. S., Leong S. S., Kawinski D., Karr J. P., Rosenthal H., Ming Chu T., Mirand E. A. and Murphy G. P.: LNCaP model of human prostate carcinoma. Cancer Res. 43 (1983) 1809-1818.

11. Berns E. M. J. J., de Boer W. and Mulder E.: Androgen dependent growth regulation and the release of specific protein(s) by the androgen receptor containing human prostate tumor cell line LNCaP. Prostate 9 (1986) 247-259.

12. Schuurmans A. L. G., Bolt J., Voorhorst M. M., Blankenstein R. A. and Mulder E.: Regulation of growth and epidermal growth factor receptor levels of prostate tumor cells by different steroids. Int. J. Cancer 42 (1988) 917-922.

13. Schulz P., Bauer H. W. and Fittler F.: Steroid hormone regulation of prostatic acid phosphatase expression in cultured human prostatic carcinoma cells. Biol. Chem. Hoppe-Seyler 366 (1985) 1033-1039.

14. Schuurmans A. L. G., Bolt J. and Mulder E.: Androgens stimulate both growth rate and epidermal growth factor receptor activity of the human prostate tumor cell LNCaP. Prostate 12 (1988) 55-63.

15. Schuurmans A. L. G., Bolt J. and Mulder E.: Androgens and transforming growth factor $\alpha$ modulate the growth response to epidermal growth factor in human prostatic tumor cells (LNCaP). Molec. Cell. Endocr. 60 (1988) 101-104.

16. Schuurmans A. L. G., Bolt J., Veldscholte J, and Mulder E.: Stimulatory effects of antiandrogens on LNCaP prostate tumor cell growth, EGF-receptor level and acid phosphatase secretion. J. Steroid Biochem. Molec. Biol. 37 (1990) 849-853.

17. Veldscholte J., Voorhorst-Ogink M. M., Bolt-de Vries J., Rooy H. C. J. van, Trapman J. and Mulder E.: Unusual specificity of the androgen receptor in the human prostate tumor cell line LNCaP: high affinity for progestagenic and estrogenic steroids. Biochim. Biophys. Acta 1052 (1990) 187-194.

18. Trapman J., Ris-Stalpers C., Korput J. A. G. M. van der, Kuiper G. G. J. M., Faber P. W., Romijn J. C., Mulder E. and Brinkmann A. O.: The androgen receptor: functional structure and expression in transplanted human prostate tumor cell lines. J. Steroid Biochem. Molec. Biol. 37 (1990) 837-842.
19. Traish A. M. and Wotiz H. H.: Prostatic epidermal growth factor receptors and their regulation by androgens. Endocrinology 121 (1987) 1461-1467.

20. Eaton C. L., France T. D. and Davies P.: Regulation of epidermal growth factor (EGF) receptor in neoplastic and non-neoplastic prostatic cell lines. J. Steroid Biochem. Molec. Biol. (1991) In press.

21. Davies P. and Eaton C. L.: Binding of epidermal growth factor by human normal, hypertrophic, and carcinomatous prostate. Prostate 14 (1989) 123-132.

22. Davidson N. E., Gelmann E. P., Lippman M. E. and Dickson R. B.: Epidermal growth factor receptor gene expression in estrogen receptor-positive and negative human breast cancer cell lines. Molec. Endocr. 1 (1987) 216-223.

23. Wilding G., Zugmeier G., Knabbe C., Flanders K. and Gelmann E.: Differential effects of transforming growth factor $\beta$ on human prostate cancer cells in vitro. Molec. Cell. Endocr. 62 (1989) 79-87.

24. Luetteke N. C., Michalopoulos G. K., Teixido J., Gilmore R., Massagué J. and Lee D. C.: Characterization of high molecular weight transforming growth factor $\alpha$ produced by rat hepatocellular carcinoma cells. Biochemistry 27 (1988) 6487-6494.

25. Wong S. T., Winchell L. F., McCune B. K., Earp H. S. Texido J., Massagué J., Herman B. and Lee D. C.: The TGF- $\alpha$ precursor expressed on the cell surface binds to the EGF receptor on adjacent cells, leading to signal transduction. Cell 56 (1989) 495-506.

26. Branchman R., Lindquist P. B., Nagshima M., Kohr W., Lipari T., Napier M. and Derynck R.: Transmembrane TGF- $\alpha$ precursors activate EGF/TGF- $\alpha$ receptors. Cell 56 (1989) 691-700.

27. Kobrin M. S., Samsoondar J. and Kudlow J. E. $\alpha$-Transforming growth factor secreted by untransformed bovine anterior pituitary cells in culture. J. Biol. Chem. 261 (1986) 14,414-14,419.

28. Trapman J., Jenster G., Riegman P., Klaassen P., Korput J. A. G. M. van der, Steenbrugge G. J. van and Rimijn J. C.: Expression of (proto)oncogenes and genes encoding growth factors and growth factor receptors and prostate antigen in human prostate cancer cells. In Progress in Cancer Research and Therapy; Hormones and Cancer, 3 (Edited by F. Bresciani, R. J. King, M. E. Lippman and J.-P. Raynaud). Raven Press, New York, Vol. 35 (1988) pp. 102-109.

29. Wilding G., Valverius E., Knabbe C. and Gelmann E. P.: Role of transforming growth factor- $\alpha$ in human prostate cancer cell growth. Prostate 15 (1989) 1-12.

30. Connolly J. M. and Rose D. P.: Production of epidermal growth factor and transforming growth factor- $\alpha$ by the androgen-responsive LNCaP human prostate cancer cell line. Prostate 16 (1990) 209-218.

31. Knabbe C., Kellner U., Sohrt K. and Voigt K. D.: Polyanions inhibit growth of human prostate carcinoma cells by inactivation of growth factor action. $J$. Cancer Res. Clin. Oncol. 116 (1990) 459.

32. Berns P. M. J. J., Schuurmans A. L. G., Bolt J., Lamb D., Foekens J. and Mulden E.: Antiproliferative effects of suramin on androgen responsive tumor cells. Eur. $J$. Cancer 26 (1990) 470-474.

33. Wilding G., Chen M. and Gelmann E. P.: Aberrant response in vitro of hormone-responsive prostate cancer cells to antiandrogens. Prostate 14 (1989) 103-115.

34. Carlstedt-Duke J., Strömstedt P.-E., Persson B., Cederlund E., Gustafsson J.-A. and Jörnvall H.: Identification of hormone-interacting amino acid residues within the steroid-binding domain of the glucocorticoid receptor in relation to other steroid hormone receptors. J. Biol. Chem. 263 (1988) 6842-6846.

35. Baulieu E. E.: Contragestion and other clinical applications of RU 486, an anti-progesterone at the receptor Science 245 (1989) 1351-1357. 